\title{
ANALISIS PENGARUH KEBIJAKAN GIRO WAJIB MINIMUM (GWM), POSISI DEVISA NETTO (PDN), LOAN TO DEPOSIT RATIO (LDR), CADANGAN KERUGIAN PENURUNAN NILAI (CKPN), DAN SUKU BUNGA SBI TERHADAP PERUBAHAN LABA
}

(Studi Pada Bank Umum Swasta Nasional Devisa di Indonesia Periode 2009-2013)

\author{
Dwi Widi Pratito S.N., SE, MM \\ tito_pratito@yahoo.com \\ Diana Puspitasari, SE, MM \\ dianapuspitasari887@yahoo.com \\ Fakultas Ekonomi, Universitas Semarang
}

\begin{abstract}
This research is performed on order to test the influence of the variable Giro Wajib Minimum (GWM), Posisi Devisa Netto (PDN), Loan to Deposit Ratio (LDR), Cadangan Kerugian Penurunan Nilai (CKPN), and SBI Rate toward Earning change (Study on Devisa Bank Period 2009-2013). Methodology research as the sample used purposive sampling, sample was accured 34 Devisa Bank in Indonesia. Data analysis with multi liniear regression of ordinary least square and hypothesis test used $t$-statistic and $F$ statistic at level of significance 5\%, a clasic assumption examination which consist of data normality test, multicolinearity test, heteroskedasticity test and autocorrelation test is also being done to test the hypotheses. During research period show as variabel and data research was normal distributed. Based on test, multicolinearity test, heteroskedasticity test and autocorrelation test classic assumption deviation has no founded, this indicate that the available data has fulfill the condition to use multi linear regression model. This result of research show that variable PDN, CKPN and Suku Bunga SBI did not influence significant toward Earning Change. Variable GWM and LDR significant influence toward Earning Change. Prediction capability from these five variable toward Earning Change is $62 \%$ where the balance $38 \%$ is affected to other factor which was not to be entered to research model.
\end{abstract}

Key Words : Giro Wajib Minimum (GWM), Posisi Devisa Netto (PDN), Loan to Deposit Ratio (LDR), Cadangan Kerugian Penurunan Nilai (CKPN), SBI Rate and Earning change

\section{ABSTRAKSI}

Penelitian ini dilakukan untuk menganalisis pengaruh rasio Giro Wajib Minimum (GWM), Posisi Devisa Netto (PDN), Loan to Deposit Ratio (LDR), Cadangan Kerugian Penurunan Nilai (CKPN), dan tingkat suku bunga SBI terhadap Perubahan Laba (Studi Pada Bank Umum Swasta Nasional Devisa di Indonesia Periode 2009-2013). Metodologi pengambilan sampel dengan purposive sampling sehingga diperoleh sebanyak 34 Bank Devisa di IndonesModel yang digunakan adalah model regresi linier berganda yang telah diuji dengan pengujian asumsi klasik yang meliputi uji normalitas data, uji multikolinearitas, uji heteroskedastisitas dan uji autokorelasi. Untuk menguji Hipotesis 
mengenai pengaruh variabel independen terhadap variabel dependen digunakan uji statistik t-test dan uji statistik F-test dengan taraf signifikansi 5\%. Sedangkan untuk mengetahui seberapa besar pengaruh secara simultan antara ketujuh variabel independen terhadap variabel dependen maka dengan melihat koefisien determinasinya $\left(\mathrm{R}^{2}\right)$. Hasil penelitian ini menemukan bahwa secara parsial variabel, Posisi Devisa Netto (PDN), Cadangan Kerugian Penurunan Nilai (CKPN), dan tingkat suku bunga SBI tidak berpengaruh signifikan terhadap Perubahan Laba, sedangkan variabel Giro Wajib Minimum (GWM) dan Loan to Deposit Ratio (LDR), memiliki pengaruh signifikan terhadap Perubahan Laba.

Kata Kunci : Giro Wajib Minimum (GWM), Posisi Devisa Netto (PDN), Loan to Deposit Ratio (LDR), Cadangan Kerugian Penurunan Nilai (CKPN), Suku Bunga SBI, dan Perubahan Laba.

\section{PENDAHULUAN}

Kriteria penilaian kinerja keuangan bank dapat dilakukan dengan menggunakan pendekatan kualitatif atas berbagai aspek yang berpengaruh terhadap kondisi dan perkembangan bank, yaitu dengan perhitungan rasio keuangan. Analisis rasio keuangan dapat digunakan untuk membantu para pelaku bisnis dalam menilai suatu kondisi keuangan perusahaan yang bersangkutan. Analisis rasio keuangan juga dapat digunakan sebagai sistem peringatan dini terhadap kemunduran kondisi keuangan suatu perusahaan. Oleh karena itu rasio keuangan bermanfaat untuk menilai kinerja keuangan yang bersangkutan. Salah ukuran untuk melihat kinerja keuangan perbankan adalah melalui perubahan laba. Untuk memprediksi dan menganalisis penyebab terjadinya perubahan laba dapat digunakan dengan analisis rasio keuangan. Rasio keuangan yang digunakan dalam penelitian ini adalah Giro Wajib Minimum (GWM), Posisi Devisa Netto (PDN), Loan to Deposit Ratio (LDR), Cadangan Kerugian Penurunan Nilai (CKPN) asset keuangan terhadap asset produktif. Alasan dipilihnya rasio keuangan Giro Wajib Minimum (GWM), dan Loan to Deposit Ratio (LDR) sebagai variabel penelitian karena didasarkan pada ketidakkonsistenan perbedaan hasil terdahulu mengenai pengaruh Giro Wajib Minimum (GWM) terhadap perubahan laba. Sedangkan penggunaan variabel Posisi Devisa Netto (PDN) dan Cadangan Kerugian Penurunan Nilai (CKPN) asset keuangan terhadap asset produktif dikarenakan belum pernah digunakannya variabel ini untuk menganalisis pengaruhnya terhadap perubahan laba. Sehingga diharapkan ada celah informasi baru yang bermanfaat dalam pengambilan keputusan atau kebijakan di masa yang akan datang.

\section{RUMUSAN MASALAH}

Berdasarkan latar belakang permasalahan yang telah diuraikan di atas, maka ditemukan research problem sebagai berikut : laba yang diperoleh Bank Umum Swasta Nasional Devisa di Indonesia selama periode 2009-2013 menunjukkan kondisi kecenderungan menurun, dan juga ditemukan adanya research gap dari perbedaan hasil penelitian-penelitian terdahulu, sehingga berdasarkan research problem tersebut maka dapat disusun pertanyaan penelitian atau research question sebagai berikut :

1. Bagaimana pengaruh Giro Wajib Minimum (GWM) terhadap perubahan laba?

2. Bagaimana pengaruh Posisi Devisa Netto (PDN) terhadap perubahan laba? 
3. Bagaimana pengaruh Loan to Deposit Ratio (LDR) terhadap perubahan laba?

4. Bagaimana pengaruh Cadangan Kerugian Penurunan Nilai (CKPN) terhadap perubahan laba?

5. Bagaimanakan pengaruh Suku Bunga SBI terhadap perubahan laba?

Sesuai dengan permasalahan dan pertanyaan penelitian di atas maka tujuan yang hendak dicapai dalam penelitian ini dapat dirinci sebagai berikut :

1. Untuk menganalisis pengaruh Giro Wajib Minimum (GWM) terhadap perubahan laba perusahaan perbankan.

2. Untuk menganalisis pengaruh Posisi Devisa Netto (PDN) terhadap perubahan laba perusahaan perbankan.

3. Untuk menganalisis pengaruh Loan to Deposit Ratio (LDR) terhadap perubahan laba perusahaan perbankan.

4. Untuk menganalisis pengaruh Cadangan Kerugian Penurunan Nilai (CKPN) terhadap perubahan laba perusahaan perbankan.

5. Untuk menganalisis pengaruh Suku Bunga SBI terhadap perubahan laba perusahaan perbankan

\section{Manfaat Penelitian}

Manfaat hasil penelitian yang akan disampaikan adalah sebagai berikut :

1. Bagi perusahaan perbankan sendiri, hasil penelitian ini dapat dijadikan sumber informasi dalam merumuskan kebijakan sehubungan dengan perencanaan pengelolaan dana yang akan digunakan untuk meningkatkan kinerja keuangan yang bermuara pada peningkatan laba untuk periode yang akan datang.

2. Sebagai bahan pertimbangan dan informasi bagi para investor untuk pengambilan keputusan investasi.

3. Bagi para peneliti diharapkan penelitian ini dapat memberikan kontribusi literatur dan memberikan bekal pengetahuan sebagai bukti empiris di bidang perbankan dan untuk melengkapi penelitian-penelitian terdahulu yang pernah dilakukan oleh peneliti sebelumnya, dan dapat digunakan sebagai bahan rujukan atau referensi bagi para akademisi yang ingin melakukan penelitian serupa selanjutnya, yang erat kaitannya dengan rasio keuangan bank dan perubahan laba.

\section{KAJIAN PUSTAKA DAN PENGEMBANGAN HIPOTESIS}

\section{Teori Keagenan}

Teori keagenan (agency theory) yang dikemukakan oleh Jensen dan Meckling (1976) menyatakan bahwa umumnya semua pemegang saham yang termasuk dalam level manajemen memiliki kepentingan tersendiri, salah satunya adalah dalam hal pengungkapan informasi. Biasanya manajer memiliki akses informasi (keuangan) atas prospek perusahaan yang tidak dimiliki oleh pihak luar perusahaan. Informasi ini tidak mungkin bisa keluar ke publik begitu saja karena pihak internal harus memenuhi regulasi yang ada dalam menyampaikan informasi ke publik. Informasi tersebut selalu ditahan perusahaan dan menginformasikannya pada waktu yang tepat. Pengumuman laba mengandung informasi yang digunakan investor untuk mengambil keputusan dalam berinvestasi dan memprediksi prospek perusahaan di masa datang. Bila pihak manajemen mengumumkan kenaikan laba, maka investor akan menangkap informasi ini sebagai sinyal bahwa prospek perusahaan dalam kondisi keuangannya relatif baik untuk masa mendatang. Namun jika manajemen mengumumkan penurunan laba, hal ini dijadikan sinyal oleh investor bahwa kondisi perusahaan relatif tidak baik di masa mendatang. Signal perusahaan berupa informasi keuangan dapat dianalisis dengan menghitung angkaangka keuangan yang terdapat di dalam 
laporan keungan melalui penghitungan rasio keuangan.

\section{Kinerja Keuangan Bank}

Kinerja keuangan suatu perusahaan yang tercermin dalam laporan keuangan perusahaan merupakan hal yang sangat penting yang harus dicapai, dimana kinerja keuangan yang dilaporkan oleh perusahaan merupakan salah satu indikator keberhasilan atau bahkan kemunduran dari suatu kondisi yang krusial di dalam perusahaan, dalam hal ini berlaku juga untuk bank. Bank sebagai pengelola dana dari pihak ketiga wajib mempertahankan kepercayaan masyarakat terhadap kinerja bank yang bersangkutan. Transparansi kejujuran dalam penyampaian laporan keuangan kepada publik wajib disampaikan untuk memenuhi kebutuhan informasi sebagai dasar kebijakan pembuatan keputusan. Achmad dan Kusno (2003) menjelaskan bahwa penilaian kinerja keuangan bank dimaksudkan untuk menilai keberhasilan para manajemen bank di dalam mengelola usahanya. Penilaian ini dapat diproksikan dengan Indicator financial ratio, ketentuan penilaian kesehatan perbankan (peraturan Bank Indonesia), dan fluktuasi harga saham. Dalam penelitian ini digunakan indicator financial ratio bank dalam menilai kinerja keuangan bank yang dimaksud. Salah satu ukuran penilaian kinerja keuangan perbankan adalah melalui perubahan laba yang dapat digunakan sebagai parameter penilaian oleh manajemen perusahaan dan investor.

\section{Analisis Rasio Keuangan Bank}

Analisis rasio keuangan digunakan sebagai dasar perencanaan pengambilan keputusan untuk memperoleh gambaran perkembangan keuangan dan posisi keuangan perusahaan di masa yang akan datang (Usman, 2003). Analisis rasio keuangan menggambarkan hubungan matematis antara suatu jumlah tertentu dengan jumlah yang lain dalam laporan keuangan dengan cara mengembangkan ukuran-ukuran kinerja bank yang telah distandarisasi yang dapat memberikan petunjuk, gejala, serta informasi keuangan lainnya mengenai keadaan suatu bank, oleh karena itu rasio keuangan bermanfaat dalam menilai suatu kondisi bank (Wahyuningsih dan Hadinugroho, 2004).

\section{Perubahan Laba}

Sifat laba yang berubah-ubah dari tahun ke tahun membuat informasi dalam laporan keuangan akan sangat bermanfaat dalam proses pengambilan keputusan apabila dapat diprediksi terutama bagi pihak-pihak yang akan menanamkan modalnya di perusahaan. Laba menurut PSAK (1994) dalam Adhista (2009), adalah kenaikan manfaat ekonomi selama satu periode akuntansi dalam bentuk pemasukan atau penambahan aktiva atau penurunan kewajiban yang melibatkan kenaikan ekuitas yang tidak berasal dari kontribusi penanaman modal. Tujuan pelaporan laba memberikan informasi yang berguna dalam pengambilan keputusan investasi dan keputusan kredit, berguna juga dalam meramal prospek aliran kas dan laba masa depan dan diharapkan memberikan informasi tentang sumber daya perusahaan, klaim terhadap sumber daya tersebut, dan perubahan sumber daya tersebut. Perubahan laba perusahaan yang baik mencerminkan bahwa kinerja perusahaan juga baik karena laba merupakan ukuran kinerja dari suatu perusahaan, maka semakin tinggi laba yang dicapai perusahaan, mengindikasikan semakin tinggi kinerja perusahaan.

\section{Hipotesis}

$\mathrm{H}_{1}$ : Giro Wajib Minimum (GWM) berpengaruh negatif signifikan terhadap perubahan laba. 
$\mathrm{H}_{2}$ : Giro Wajib Minimum (GWM) berpengaruh negatif signifikan terhadap perubahan laba.

$\mathrm{H} 3$ : Loan to Deposit Ratio berpengaruh positif signifikan terhadap perubahan laba.

$\mathrm{H} 4$ : Cadangan Kerugian Penurunan Nilai (CKPN) berpengaruh negatif signifikan terhadap perubahan laba.

$\mathrm{H}_{5}$ : Tingkat Suku Bunga SBI berpengaruh positif signifikan terhadap perubahan laba.

\section{Kerangka Pemikiran}

Pengaruh Giro Wajib Minimum (GWM), Posisi Devisa Netto (PDN), Loan to Deposit Ratio (LDR), Cadangan Kerugian Penurunan Nilai (CKPN) dan Suku Bunga SBI terhadap Perubahan Laba.

\section{METODA PENELITIAN}

\section{Jenis dan Sumber Data}

Jenis data yang digunakan dalam penelitian ini adalah data sekunder berupa data suku Bunga SBI, serta data laporan keuangan tahunan Bank Umum Swasta Nasional Devisa yang ada di Indonesia periode 2009-2013. Sumber data diperoleh dari direktori Perbankan Indonesia dan website Bank Indonesia, yaitu www.bi.go.id. Sedangkan untuk data penelitian merupakan pooling data yaitu gabungan antara deret waktu (time series) dan cross section selama kurun waktu 2009 sampai dengan tahun 2013, sehingga diperoleh jumlah observasi (titik pengamatan) sebanyak 170 titik pengamatan, yang didapat dari 34 X 5 (perkalian antara jumlah sampel dengan periode tahun pengamatan).

\section{Populasi dan Sampel}

Populasi yang digunakan dalam penelitian ini adalah seluruh Bank Umum Swasta Nasional Devisa yang ada di Indonesia yang terdaftar dalam direktori Bank Indonesia. Metode yang digunakan dalam penentuan sampel adalah purpossive sampling, yaitu sampel ditarik sejumlah tertentu dari populasi emiten dengan menggunakan kriteria tertentu (Ghozali, 2006). Kriteria penarikan sampel dalam penelitian ini adalah :

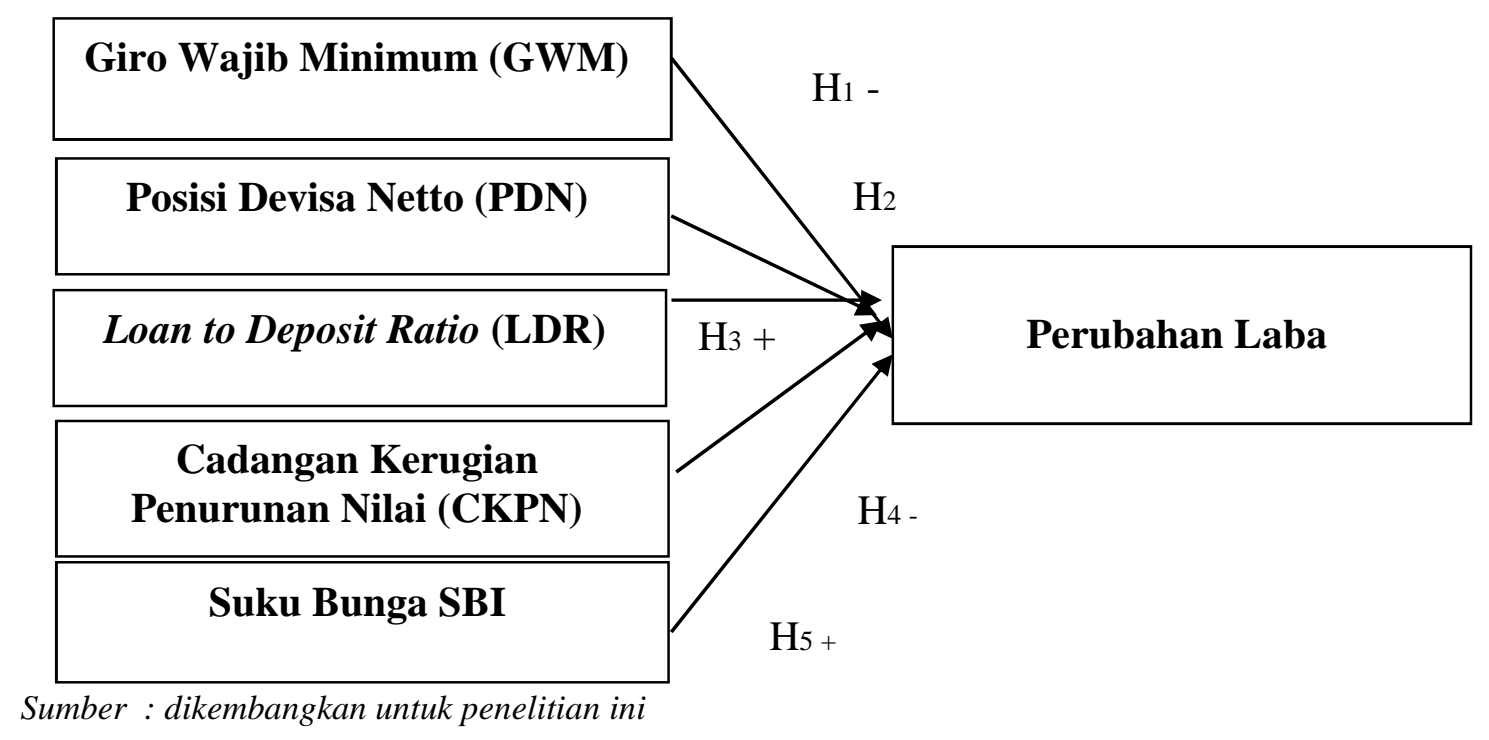


1. Bank Devisa di Indonesia yang menyajikan laporan keuangan selama lima tahun berturut-turut, dari 31 Desember 2009 sampai dengan 31 Desember 2013 dan disampaikan kepada Bank Indonesia.

2. Bank Devisa di Indonesia yang menyajikan rasio secara lengkap yang sesuai dengan variabel yang akan diteliti, dan sesuai dengan periode pengamatan, serta disampaikan kepada Bank Indonesia, sehingga diperoleh sampel sebanyak 34 Bank Umum Swasta Nasional Devisa.

\section{Metode Pengumpulan Data}

Dengan mengumpulkan data sekunder yang berupa data Suku Bunga SBI dan laporan keungan tahunan yang diperoleh dari Direktori Perbankan 2014 untuk pengambilan data rasio keuangan periode 2009-2013, serta website bank Indonesia untuk pengambilan data tingkat suku bunga.

\section{Definisi Operasional Variabel Variabel Dependen}

Variabel dependen dalam penelitian ini adalah perubahan laba sebelum pajak. Penggunaan laba sebelum pajak sebagai indikator perubahan laba untuk menghindari pengaruh penetapan tarif pajak yang berbeda antar periode yang dianalisis (Bahtiar Usman, 2003).

Perubahan laba adalah :

$$
\Delta Y i, t=\frac{Y_{(i, t)}-Y_{(i, t-1)}}{Y_{(i, t-1)}}
$$

Dimana :

$$
\begin{aligned}
Y i, t= & \text { Perubahan laba pada periode } \mathrm{t} \\
& \text { untuk bank } \mathrm{i}
\end{aligned}
$$

Yi,t = Laba pada periode $\mathrm{t}$ untuk bank i

Yi,t-1 = Laba pada periode sebelum $\mathrm{t}$ untuk bank i
1. Giro Wajib Minimum (GWM) : merupakan rasio perbandingan antara jumlah saldo giro pada Bank Indonesia dengan pihak ketiga (Surat Edaran BI No. 3/30DNP tanggal 14 Desember 2001).

$$
\mathrm{GWM}=\frac{\mathrm{SGBI}}{\mathrm{DPK}} \times 100 \%
$$

Keterangan :

GWM = Giro Wajib Minimum

SGBI = Jumlah saldo giro pada BI

DPK = Jumlah Dana Pihak Ketiga

2. Posisi Devisa Netto (PDN) : merupakan rasio perbandingan antara selisih aktiva valas dan pasiva valas ditambah dengan selisih bersih off balance sheet valas terhadap modal. (Surat Edaran BI No. 3/30DNP tanggal 14 Desember 2001).

$$
\mathrm{PDN}=\frac{(\mathrm{AV}-\mathrm{PV})+\mathrm{BS}}{\mathrm{Modal}} \mathrm{X} 100 \%
$$

Keterangan :

PDN = Posisi Devisa Netto

$\mathrm{AV}=$ Aktiva Valas

PV = Pasiva Valas

$\mathrm{BS}=$ selisih bersih off balance sheet

3. Loan to Deposit Ratio (LDR) : merupakan rasio perbandingan antara jumlah kredit yang diberikan terhadap jumlah dana pihak ketiga. (Surat Edaran BI No. 3/30DNP tanggal 14 Desember 2001).

$$
\mathrm{LDR}=\frac{\mathrm{KR}}{\mathrm{DPK}} \mathrm{X} 100 \%
$$

Keterangan :

LDR = Loan to Deposit Ratio

$\mathrm{KR}=$ Jumlah Kredit Yang Diberikan

DPK = Jumlah Dana Pihak Ketiga

\section{Variabel Independen}


4. Cadangan Kerugian Penurunan Nilai (CKPN) : Pembentukan CKPN mempertimbangkan tiga komponen yaitu Probability of Default (PD), Loss Given Default (LGD) atau discounted recovery rate, dan Exposure at Default (EAD) dari kelompok kredit (Fatya, 2013).

\section{CKPN : (EAD x PD x LGD) X 100\%}

5. Suku Bunga SBI : adalah tingkat suku bunga SBI tahunan yang dikeluarkan tiap bulan. Tingkat suku Bunga bank sentral diproksikan dengan tingkat Suku Bunga Sertifikat Bank Indonesia atau SBI (Husnan, 1998).

Penelitian ini menggunakan analisis regresi berganda dengan persamaan kuadrat terkecil atau ordinary least square (OLS) dengan persamaan sebagai berikut :

$\mathrm{Y}=\alpha+\beta_{1} \mathrm{X}_{1}+\beta_{2} \mathrm{X}_{2}+\beta_{3} \mathrm{X}_{3}+\beta_{4} \mathrm{X}_{4}+\beta_{5} \mathrm{X}_{5} \mathrm{e}$

Keterangan :

Y : Perubahan Laba

$\alpha \quad$ : Konstanta

$\beta_{1}, \beta_{2}, \beta_{3}, \beta_{4}, \beta_{5} \quad$ : Koefisien regresi

$\mathrm{X}_{1} \quad$ : Giro Wajib Minimum $(\mathrm{GWM})$

$\mathrm{X}_{2} \quad$ : Posisi Devisa Netto (PDN)
$\mathrm{X}_{3}$ : Loan to Deposit Ratio (LDR)

$\mathrm{X}_{4}$ : Cadangan Kerugian Penurunan Nilai (CKPN)

$\mathrm{X}_{5} \quad$ : Suku Bunga SBI

e : Standar error

\section{PEMBAHASAN}

\section{Analisis Statistik Deskriptif}

Setelah melalui proses analisis diperoleh bahwa dari 170 data pengamatan ternyata tidak memenuhi normalitas. Maka dilakukan upaya perbaikan data penelitian dengan cara mengeluarkan data yang terindikasi sebagai data ekstrim, baik yang terlalu tinggi ataupun yang terlalu rendah. Seperti terlihat pada nilai Giro Wajib Minimum (GWM) dan nilai Posisi Devisa Netto (PDN) pada tabel di atas dimana nilai GWM tertinggi sebesar $505 \%$, diindikasikan sebagai data ekstrim yang terlalu tinggi, sebesar $505 \%$ dana pihak ketiga dialokasikan untuk GWM, hal ini menyebabkan terbatasnya kemampuan penyaluran dana yang dilakukan oleh bank. Semakin tinggi GWM semakin tinggi pula Cost of Loanable Fund sehingga berpengaruh terhadap penurunan laba bank.

Tabel 1. Data Deskriptif Sebelum Outlier Dihilangkan

\begin{tabular}{|c|c|c|c|c|c|}
\hline & $\mathrm{N}$ & Range & Minimum & Maximum & Std. Deviation \\
\hline GWM & 170 & 500.00 & 5.00 & 505.00 & 38.20303 \\
\hline PDN & 170 & 310.00 & -2.00 & 308.00 & 25.53107 \\
\hline LDR & 170 & 112.42 & 6.58 & 119.00 & 21.61242 \\
\hline CKPN & 170 & 127.58 & .06 & 127.64 & 22.83346 \\
\hline SSBI & 170 & 2.42 & 4.80 & 7.22 & .91467 \\
\hline PERUB.LABA & 170 & 49.68 & -76.75 & 98.00 & 3.42341 \\
\hline Valid N (listwise) & 170 & & & & \\
\hline
\end{tabular}

Sumber : Data Sekunder, yang diolah 
Tabel 2. Descriptive Statistics

\begin{tabular}{|l|r|r|r|r|r|}
\hline & $\mathrm{N}$ & Minimum & Maximum & Mean & Std. Deviation \\
\hline GWM & 150 & 5.00 & 9.00 & 6.0023 & 1.14672 \\
PDN & 150 & 1.05 & 23.67 & 8.1963 & 5.48095 \\
LDR & 150 & 11.88 & 119.00 & 83.5883 & 15.35920 \\
CKPN & 150 & .06 & 56.00 & 2.5621 & 7.32192 \\
SSBI & 150 & 4.80 & 7.22 & 5.8464 & .90404 \\
PERUB.LABA & 150 & -76.75 & 98.00 & 30.1123 & 34.80034 \\
Valid N (listwise) & 150 & & & & \\
\hline
\end{tabular}

Sumber : Data Sekunder, yang diolah

Nilai PDN tertinggi sebesar $308 \%$. Nilai ini diindikasikan sebagai data ekstrim yang terlalu tinggi. Bank Indonesia selaku pemegang otoritas moneter menetapkan bahwa bank umum devisa wajib mengelola dan memelihara PDN setinggi-tingginya 20\% dari modal bank. Penetapan besarnya PDN ini dimaksudkan agar bank-bank dalam mengambil kebijakan posisi pengelolaan valuta asing selalu dalam pengawasan. Apabila terjadi perbedaan nilai tukar mendadak dalam jumlah besar tidak mengalami gangguan yang dapat berakibat fatal.

Hasil pengujian setelah outlier dihilangkan dapat disajikan pada tabel 2 . Berdasarkan tabel 2 diketahui bahwa data awal yang dianalisis sebanyak 170 yang diperoleh dari laporan keuangan 34 perusahaan Bank Umum Swasta Nasional Devisa dengan periode pengamatan selama tahun 2009-2013. Namun demikian dari hasil analisis diperoleh adanya masalah tidak terpenuhinya normalitas data, sehingga 20 buah data harus dikeluarkan dari analisis data karena menjadi data outlier. Sehingga didapat data yang baru sebanyak 150. Penentuan outlier diperoleh karena adanya data-data ekstrim yang ada dalam penelitian ini.

\section{Uji Normalitas}

\section{Grafik Histogram Hasil Uji Normalitas Setelah Outlier Dihilangkan}

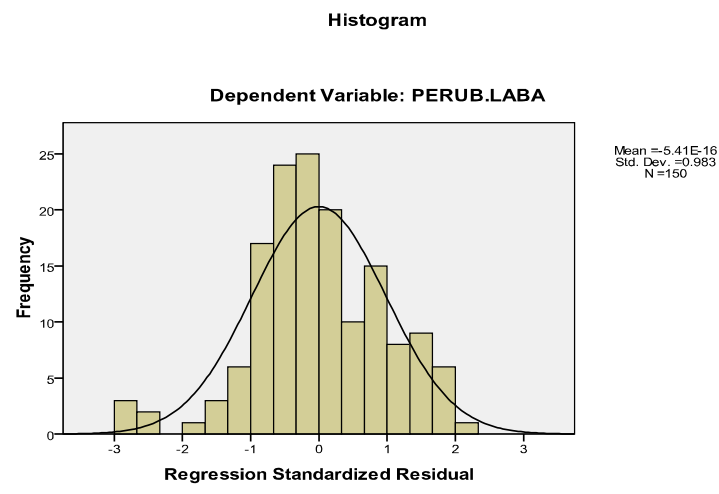

Darı gambar d1 atas terlıhat bahwa pola distribusi mendekati normal karena data mengikuti arah garis garifk histogramnya. Sedangkan hasil uji normalitas data dengan Normal Probability Plot terlihat dalam gambar di bawah ini :

\section{Hasil Uji Normal Probability Plot Setelah Outlier Dihilangkan}

\section{Normal P-P Plot of Regression Standardized Residual}

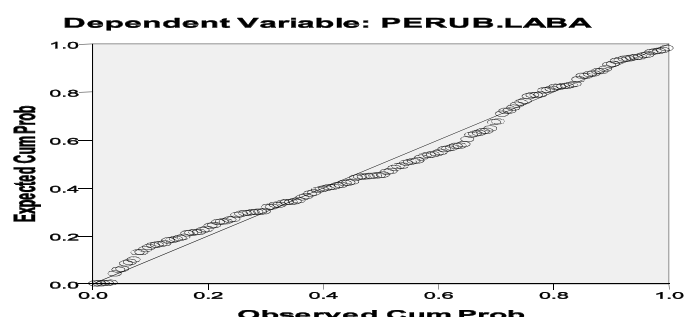


Sumber : Data Sekunder, yang diolah

di atas menunjukkan bahwa data menyebar di sekitar garis diagonal dan mengikuti arah garis diagonal, dan menunjukkan pola distribusi normal, sehingga dapat disimpulkan bahwa asumsi normalitas telah terpenuhi.

\section{Uji Multikolinearitas}

Berdasarkan aturan VIF (Variance Inflation Factor) dan Tolerance, maka apabila VIF melebihi angka 10 atau Tolerance kurang dari 0,10 , maka dinyatakan terjadi gejala multikolinieritas, sebaliknya apabila harga VIF kurang dari 10 atau tolerance lebih dari 0,10 , maka dinyatakan tidak terjadi gejala multikolinieritas.

\section{Tabel 3. Hasil Uji Multikolinearitas Setelah Outlier Dihilangkan}

\begin{tabular}{|c|r|r|}
\hline \multirow{2}{*}{ Model } & \multicolumn{2}{|c|}{ Collinearity Statistics } \\
\cline { 2 - 3 } & Tolerance & \multicolumn{1}{|c|}{ VIF } \\
\hline 1 & (Constant) & \\
GWM & .965 & 1.036 \\
PDN & .961 & 1.041 \\
LDR & .919 & 1.088 \\
CKPN & .961 & 1.040 \\
SSBI & .927 & 1.079 \\
\hline
\end{tabular}

Sumber: Data Sekunder, yang diolah

Berdasarkan tabel diatas dapat diketahui bahwa semua variabel independen memiliki nilai tolerance berada di bawah 1 dan nilai VIF jauh di bawah 10 . Dengan demikian dapat dikatakan bahwa model yang terbentuk tidak memiliki gejala multikolinearitas.

\section{Uji Heteroskedastisitas}

Uji Heteroskedastisitas digunakan untuk menguji apakah dalam model regresi terjadi ketidaksamaan variance dari residual satu pengamatan ke peng- amatan yang lain (Imam Ghozali, 2005). Jika variance dari residual satu pengamatan ke pengamatan lain tetap, maka disebut homoskedastisitas dan jika berbeda disebut heteroskedastisitas. Model regresi yang baik adalah yang tidak terjadi heteroskedastisitas (Ghozali, 2005).

Ada atau tidaknya problem heteroskedastisitas dalam penelitian ini dapat dideteksi dengan melihat sebaran pada scatterplot dalam gambar di bawah ini.

\section{Grafik Scatterplot Setelah Outlier Dihilangkan}

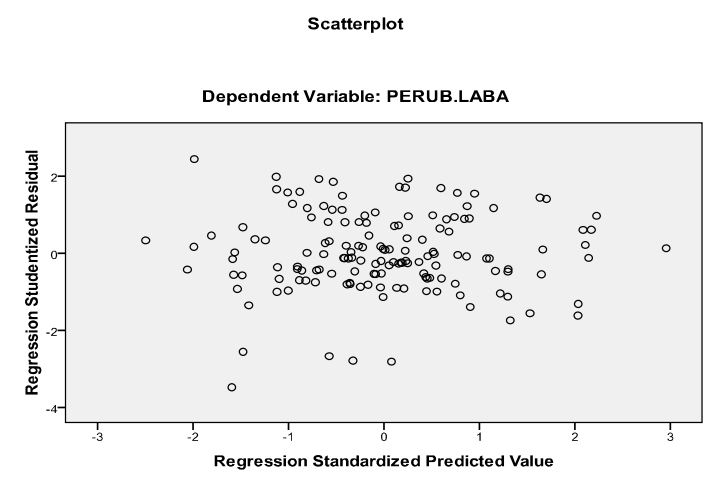

Sumber : Data Sekunder, yang diolah

Dengan melihat grafik scatterplot pada gambar di atas terlihat bahwa titik - titik menyebar secara acak dan tidak membentuk pola tertentu, serta tersebar baik di atas maupun di bawah angka 0 pada sumbu Y. Hal ini menunjukkan bahwa pada model regresi tidak terjadi gejala heteroskedastisitas.

\section{Uji Autokorelasi}

Pengujian penyimpangan autokorelasi dalam penelitian ini dengan menggunakan Durbin-Watson Test (DW-test). Hasil regresi dengan level signifikan $0,05(\alpha=$ $0,05)$ dengan jumlah variabel independen $(\mathrm{k}=5)$ dan banyaknya data $(\mathrm{N}=150)$, didapat nilai DW hitung sebesar 1,975. Besarnya DW tabel untuk dL (batas luar) $=1,665$. Besarnya DW tabel untuk dU (batas dalam) $=1,802$. Besarnya nilai 4$\mathrm{dU}=4-1,802 \Rightarrow 2,198$, dan besarnya nilai $4-\mathrm{dL}=4-1,665=>2,335$. Dari 
perhitungan tersebut di atas terlihat bahwa $1,802<1,975<2,198$ dapat disimpulkan bahwa tidak terjadi problem autokorelasi.

\section{Koefisien Determinasi (Adjusted $\boldsymbol{R}^{2}$ )}

Koefisien determinasi (adjusted $R^{2}$ ) berfungsi untuk melihat sejauhmana keseluruhan variabel independen dapat menjelaskan variabel dependen. Nilai Koefisien determinasi (adjusted $R^{2}$ ) yang kecil berarti kemampuan variabel-variabel independen dalam menjelaskan variasi variabel dependen adalah terbatas (Ghozali, 2005). Besarnya nilai Adjusted $R^{2}$ dapat dijelaskan pada tabel 4 di bawah ini.

Dari tabel 4 dapat diketahui bahwa pengaruh kelima variabel bebas atau variabel independen terhadap variabel Perubahan Laba yang dinyatakan dengan nilai Adjusted $R^{2}$, yaitu sebesar 0,620 atau 62 persen. Hal ini berarti variasi Perubahan Laba yang bisa dijelaskan oleh variabel Giro Wajib Minimum (GWM),
Posisi Devisa Netto (PDN), Loan to Deposit Ratio (LDR), Cadangan Kerugian Penurunan Nilai (CKPN) dan Suku Bunga SBI (SSBI) sebesar 62 persen. Sedangkan sisanya sebesar 100 persen- 62 persen $=$ 38 persen dijelaskan oleh sebab-sebab lain di luar model yang merupakan kontribusi variabel bebas lain di luar kelima variabel independen.

Berdasarkan perhitungan dengan $\mathrm{F}$ test dalam tabel 4.7 di atas diperoleh nilai F-hitung sebesar 95,918 dengan nilai signifikansi (sig) sebesar 0,000. Oleh karena nilai signifikansi $0,000<0,05$, maka terdapat pengaruh yang signifikan antara variabel Giro Wajib Minimum (GWM), Posisi Devisa Netto (PDN), Loan to Deposit Ratio (LDR), Cadangan Kerugian Penurunan Nilai (CKPN) dan Suku Bunga SBI (SSBI) terhadap variabel Perubahan Laba secara bersama-sama (simultan) atau dapat diartikan bahwa model dalam penelitian ini layak untuk diteliti.

Tabel 4. Koefisien Determinasi Setelah Outlier Dihilangkan

\begin{tabular}{|l|r|r|r|r|r|}
\hline Model & $\mathrm{R}$ & $\begin{array}{c}\mathrm{R} \\
\text { Square }\end{array}$ & $\begin{array}{c}\text { Adjusted R } \\
\text { Square }\end{array}$ & $\begin{array}{c}\text { Std. Error of the } \\
\text { Estimate }\end{array}$ & Durbin-Watson \\
\hline 1 & $.799^{\mathrm{a}}$ & .640 & .620 & 1.29049 & 1.975 \\
\hline
\end{tabular}

Sumber : Data Sekunder, yang diolah

Tabel 5. Hasil Uji Statistik F (Uji Goodness of Fit) Setelah Outlier Dihilangkan ANOVA $^{\mathrm{D}}$

\begin{tabular}{|rr|r|r|r|r|r|}
\hline \multicolumn{1}{|l|}{} & Sum of Squares & Df & Mean Square & F & Sig. \\
\hline 1 & Regression & 577154.547 & 5 & 115430.909 & 95.918 & $.000^{\mathrm{a}}$ \\
& Residual & 173293.976 & 144 & 1203.430 & \\
Total & 750448.523 & 149 & & \\
\hline
\end{tabular}

a. Predictors: (Constant), SSBI, GWM, CKPN, PDN, LDR

b. Dependent Variable: PERUB.LABA

Sumber : Data Sekunder, yang diolah 
Tabel 6. Hasil Uji t (Uji Parsial) Setelah Outlier Dihilangkan

Coefficients $^{a}$

\begin{tabular}{|c|c|c|c|c|c|c|c|}
\hline \multirow[b]{2}{*}{ Model } & \multicolumn{2}{|c|}{$\begin{array}{l}\text { Unstandardized } \\
\text { Coefficients }\end{array}$} & \multirow{2}{*}{\begin{tabular}{|c} 
Standardized \\
Coefficients
\end{tabular}} & \multirow[b]{2}{*}{$\mathrm{T}$} & \multirow[b]{2}{*}{ Sig. } & \multicolumn{2}{|c|}{ Collinearity Statistics } \\
\hline & B & Std. Error & & & & Tolerance & VIF \\
\hline (Constant) & 2.980 & 28.374 & & .105 & .917 & & \\
\hline GWM & -.195 & .322 & -.061 & -.322 & .048 & .965 & 1.036 \\
\hline PDN & .412 & .529 & .065 & .778 & .438 & .961 & 1.041 \\
\hline LDR & .233 & 193 & .103 & 207 & .029 & .919 & 1.088 \\
\hline CKPN & -.156 & .396 & -.033 & -.394 & 694 & .961 & 1.040 \\
\hline SSBI & -3.914 & 3.266 & -.102 & -1.199 & 233 & .927 & 1.079 \\
\hline
\end{tabular}

a. Dependent Variable: PERUB.LABA

Sumber : Data Sekunder, yang diolah

\section{Hasil Uji t (Uji Parsial)}

Uji t (Uji Parsial) dimaksudkan untuk mengetahui apakah terdapat pengaruh secara parsial (individu) dari variabel independen terhadap variabel dependen. Hasil Uji t seperti ditunjukkan pada tabel 6. Dari tabel 6, maka dapat disusun persamaan regresi linier berganda sebagai berikut :

Perubahan Laba $=2,980-0,195 G W M+$

$$
\text { 0,412PDN + 0,233LDR- 0,156CKPN }
$$

\section{- 0,3914Suku Bunga SBI}

Dari persamaan regresi linear berganda di atas dapat dilihat nilai konstanta sebesar 2,980, hal tersebut menunjukkan bahwa Perubahan Laba mempunyai nilai sebesar 2,980, variabelvariabel independen Giro Wajib Minimum (GWM), Posisi Devisa Netto (PDN), Loan to Deposit Ratio (LDR), Cadangan Kerugian Penurunan Nilai (CKPN) dan Suku Bunga SBI (SSBI) dianggap konstan. Untuk menghitung t-hitung dapat dilihat dari nilai beta unstandardized coefficient dibagi dengan standard error. Sedangkan untuk melihat dominasi variabel independen terhadap variabel dependennya tercermin dalam beta standardized coefficient.

Hasil pengujian masing-masing variabel independen terhadap variabel dependennya dapat dianalisis sebagai berikut :

1. Variabel Giro Wajib Minimum (GWM) berpengaruh negatif signifikan terhadap Perubahan Laba. Sehingga hipotesis pertama diterima.

2. Variabel Posisi Devisa Netto (PDN) berpengaruh positif tetapi tidak signifikan terhadap Perubahan Laba. Sehingga hipotesis kedua ditolak.

3. Variabel Loan to Deposit Ratio (LDR) berpengaruh positif signifikan terhadap Perubahan Laba. Sehingga hipotesis ketiga diterima.

4. Variabel Cadangan Kerugian Penurunan Nilai (CKPN) berpengaruh negatif tetapi tidak signifikan terhadap Perubahan Laba. Sehingga hipotesis keempat ditolak.

5. Variabel Suku Bunga SBI tidak berpengaruh signifikan terhadap Perubahan Laba. Sehingga hipotesis kelima ditolak. 


\section{SIMPULAN，KETERBATASAN DAN IMPLIKASI \\ Simpulan}

Selama periode pengamatan menunjukkan bahwa data penelitian berdistribusi normal. Berdasarkan uji normalitas, uji multikolinearitas, uji heteroskedastisitas, dan uji autokorelasi tidak ditemukan variabel yang menyimpang dari asumsi klasik, hal tersebut menunjukkan bahwa data yang tersedia telah memenuhi syarat untuk menggunakan model persamaan regresi linier berganda. Berdasar hasil analisis regresi linier berganda menunjukkan bahwa :

1. Variabel Giro Wajib Minimum (GWM) berpengaruh negatif signifikan terhadap Perubahan Laba. Sehingga hipotesis pertama diterima. Semakin tinggi nilai GWM akan menurunkan Perubahan Laba, karena mengindikasikan adanya dana yang menganggur terlalu tinggi sehingga laba yang dicapai tidak optimal karena dana tidak tersalurkan dengan lancar.

2. Variabel Posisi Devisa Netto (PDN) berpengaruh positif tetapi tidak signifikan terhadap Perubahan Laba. Sehingga hipotesis kedua ditolak. Hal tersebut menunjukkan bahwa peningkatan Posisi Devisa Netto (PDN) tidak mempengaruhi besarnya Perubahan Laba.

3. Variabel Loan to Deposit Ratio (LDR) berpengaruh positif signifikan terhadap Perubahan Laba. Sehingga hipotesis ketiga diterima. Semakin tinggi LDR maka akan meningkatkan Perubahan Laba. Semakin tinggi LDR maka laba perusahaan semakin meningkat (dengan asumsi bank tersebut mampu menyalurkan kredit dengan efektif, sehingga jumlah kredit macetnya akan kecil).

4. Variabel Cadangan Kerugian Penurunan Nilai (CKPN) berpengaruh negatif tetapi tidak signifikan terhadap Perubahan Laba. Sehingga hipotesis keempat ditolak. Hal tersebut menunjukkan bahwa kenaikan CKPN tidak mempengaruhi besarnya Perubahan Laba

5. Variabel Suku Bunga SBI tidak berpengaruh signifikan terhadap Perubahan Laba. Sehingga hipotesis kelima ditolak. Hal tersebut menunjukkan bahwa kenaikan Suku Bunga SBI tidak mempengaruhi besarnya Perubahan Laba.

\section{Implikasi Teoritis}

Dari hasil analisis pada bab sebelumnya, hasil penelitian ini konsisten dengan hasil penelitian terdahulu, yaitu sebagai berikut :

1. Adhista Setyarini (2009) yang menyatakan bahwa variabel LDR berpengaruh positif signifikan terhadap perubahan laba, dan menyatakan bahwa variabel GWM berpengaruh negatif signifikan terhadap perubahan laba.

2. Dewa Nyoman Gede, I Wayan Sudirman, dan Gedhe Sudjana Budhiasa (2012) yang menyatakan bahwa variabel GWM berpengaruh negatif signifikan terhadap perubahan laba.

\section{Implikasi Manajerial/Saran}

Implikasi kebijakan manajerial dalam penelitian ini adalah : dengan melihat tingkat signifikansi dan koefisien regresi maka para investor dan manajemen perusahaan perbankan khususnya Bank Devisa dalam melakukan prediksi terhadap perubahan laba pada periode mendatang sebaiknya mempertimbangkan rasio-rasio keuangan dalam hal ini khususnya rasio GWM dan LDR karena kedua rasio keuangan tersebut merupakan rasio keuangan yang berpengaruh signifikan terhadap perubahan laba. Hal ini dimaksudkan agar ketidakpastian dalam pengambilan keputusan dapat diminimalisir. 


\section{Keterbatasan Penelitian}

Penelitian ini mempunyai keterbatasan, terutama dalam hal : hasil penelitian ini menunjukkan kecilnya kemampuan variabel independen (GWM, PDN, LDR, CKPN, dan Suku Bunga SBI) dalam menjelaskan variasi variable dependen (perubahan laba) yang ditunjukkan dengan nilai adjusted $\mathrm{R}^{2}$ sebesar $62 \%$. Penelitian ini hanya terbatas menggunakan 5 rasio keuangan perbankan sebagai variabel independen (GWM, PDN, LDR, CKPN, dan Suku Bunga SBI) sehingga masih banyak diperlukan rasio keuangan perbankan yang lainnya, yang belum dimasukkan dalam penelitian ini.

\section{Agenda Penelitian Mendatang}

Pada penelitian yang akan datang terdapat beberapa hal yang perlu diperhatikan yaitu nilai adjusted $\mathrm{R}^{2}$ yang kecil yaitu sebesar $62 \%$ mengindikasikan masih ada $38 \%$ perlunya dimasukkan rasio keuangan bank yang lain yang belum dimasukkan sebagai variabel independen, misalnya serta perlunya menambahkan rentang waktu yang lebih panjang sehingga nantinya diharapkan hasil yang diperoleh akan lebih dapat digenalisir.

\section{DAFTAR PUSTAKA}

Azlika, Fatya Junissa, 2013 "Analisis Penerapan PSAK 55 (Revisi 2011) Mengenai Penurunan Nilai Kredit di PT Bank H”, Laporan Magang Universitas Indonesia (Tidak Dipublikasikan).

Endri, 2008, “Analisis Pengaruh Sertifikat Bank Indonesia (SBI), Sertifikat Wadiah Bank Indonesia (SWBI), dan Indikator Kinerja Keuangan terhadap Laba Bank Syariah", Media Riset Bisnis dan Manajemen Vol.8, No. 2, Agustus, 2008.

$\begin{array}{llr}\text { Gedhe, } & \text { Nyoman Dewa, I } & \text { Wayan } \\ & \text { Sudirman, Gede } & \text { Sudjana } \\ \text { Budhiasa, 2012, } & \text { "dampak } \\ \text { Kebijakan Moneter } & \text { Terhadap } \\ \text { Pertumbuhan ROA } & \text { Industri } \\ \text { Perbankan Regional : } & \text { Studi } \\ \text { Kasus Pada PT Bank } & \text { Sinar } \\ \text { Harapan Bali. } & \end{array}$

Ghozali, Imam, 2006, Aplikasi Analisis Multivariate Dengan Program SPSS, Badan penerbit Universitas Diponegoro, Semarang.

Hartono, Jogiyanto dan Zainuddin, 1999, "Manfaat Rasio Keuangan dalam Memprediksi Pertumbuhan Laba : Suatu Studi Empiris Pada Perusahaan Perbankan Yang Terdaftar di Bursa Efek Jakarta, Jurnal Riset Akuntansi Indonesia, Vol.2, No. 1, Januari 1999”.

Husnan, Suad, 1999, Manajemen Keuangan Teori Dan Penerapan (Keputusan Jangka Pendek), Edisi Ketiga BPFE Yogyakarta.

http://www.bi.go.id/Booklet Perbankan Indonesia

http://www.bi.go.id/Laporan Keuangan Publikasi Bank.

Kasmir, 2004, Manajemen Perbankan, PT Raja Grafindo Persada, Jakarta.

Kamco, Jeferson, 2008, Intervensi Di Bank Century, Suara Merdeka, 25 November

Loen, Boy dan Sonny Ericson, 2008, Manajemen Aktiva Pasiva Bank Devisa, PT Grasindo, Jakarta.

Peraturan Bank Indonesia No. 6/20/PBI/2004 Tentang Perubahan Atas Peraturan Bank Indonesia No. 5/13/PBI Tentang Posisi Devisa Netto Bank Umum. 
Siamat, Dahlan, 2001, Manajemen Lembaga Keuangan, Edisi Ketiga, Badan Penerbit Fakultas Ekonomi Universitas Indonesia, Jakarta.

Triono, Sunarwan Ir., 2007, "Analisis faktor-Faktor "Aang Mempengaruhi Perubahan Laba Satu Tahun Dan Dua Tahun Mendatang: Studi Pada Bank Umum Di Indonesia Periode 2001-2005.
Usman, Bahtiar, (2003), “Analisis Rasio Keuangan Dalam Memprediksi Perubahan Laba Pada Bank-Bank di Indonesia", Media Riset Bisnis dan Manajemen, Vol.3, No.1, April, 2003, pp.59-74.

Zulfadin, Rahadian dan Anita Febryani, 2003, "Analisis Kinerja Bank Devisa dan Non Devisa di Indonesia, Kajian Ekonomi dan Keuangan, Vol.7, No.4. 